\title{
Palladium-mediated Polymerization of Diazoacetamides
}

\author{
By Eiji IHARA, ${ }^{*}$ Toshimitsu HIRAREN, Tomomichi ITOH, and Kenzo INOUE*
}

Palladium-mediated polymerization of diazoacetamides bearing various substituents 1-4 is described. Homopolymerization of monomers with $n$-hexyl or 4-n-octylphenyl group on the nitrogen afforded polymers [poly( $N$-substituted carbamoylmethylene)], whose all the main chain carbons have $N$-substituted carbamoly groups. Elemental analysis of the products indicated incorporation of azo group in the main chain. Copolymerization of diazoacetamides 1-4 with a diazoketone, $(E)-1-$ diazo-4-phenyl-3-buten-2-one 5, proceeded efficiently, giving poly(substituted methylene)s with a variety of $N$-substituted carbamoyl groups in their side chains.

KEY WORDS: Poly(subsutituted methylene) Synthesis / Diazoacetamide / Poly( $N$-substituted carbamoylmethylene) / Copolymerization /

Poly(substituted methylene) synthesis (PSMS) is a method for preparing C-C main chain polymers, constructing the main chain from one carbon unit. As an example for PSMS, we and other groups have demonstrated that $\mathrm{B},{ }^{1} \mathrm{Al},{ }^{2} \mathrm{Cu},{ }^{3} \mathrm{Pd},{ }^{4}$ an $\mathrm{Rh}^{5}$ mediated polymerizations of diazocarbonyl compounds are effective to afford polymers or oligomers bearing various polar substitutents on their main chain carbons. Whereas diazoacetates and diazoketones have been utilized as diazocarbonyl compounds in these studies, ${ }^{1-5}$ further extension of the range of the available monomers will broaden the generality of the polymerization, providing a variety of repeating unit structures resulting from the monomers. In that context, expecting the formation of polymers incorporating $N$-substituted carbamoylmethylene as repeating units, we have tried to examine the reactivity of diazoacetamides with various substituents, which have not been used as monomers for any kind of polymerization so far, whereas the synthesis of poly $(N, N$-dimethylcarbamoylmethylene) has been achieved by transformation of poly(di-t-butyl fumarate), and its unique miscibility with commodity polymers has been revealed. ${ }^{6}$ The results of $\mathrm{Pd}-$ mediated polymerization of some diazoacetamides will be presented in this paper.

\section{EXPERIMENTAL}

\section{Materials}

Toluene and THF were dried over sodium and $\mathrm{Na} / \mathrm{K}$ alloy, respectively, and distilled before use. $n$-Hexylamine (Nacalai, 98\%), isopropylamine (Nacalai, 99\%), 4- $n$-octylaniline (TCI, $>95 \%), N, N^{\prime}$-dicyclohexycarbodiimide (DCC) (Nacalai, 99\%) were used as received. $\mathrm{Et}_{3} \mathrm{~N}$ (Nacalai, 99\%) was dried over $\mathrm{CaH}_{2}$, and used without further purification. Diazoacetamide $\mathbf{4},{ }^{7 \mathrm{a}}(E)$-1-diazo-4-phenyl-3-buten-2-one $\mathbf{5},{ }^{10}$ succinimidyl diazoacetate, ${ }^{7 \mathrm{a}}$ glyoxylic acid tosylhydrazone, ${ }^{11}$ and $\mathrm{PdCl}_{2}(\mathrm{MeCN})_{2},{ }^{12}$ were prepared according to the literatures.

\section{Measurements}

${ }^{1} \mathrm{H}(400 \mathrm{MHz})$ and ${ }^{13} \mathrm{C}(100 \mathrm{MHz})$ NMR spectra were recorded on a Bruker Avance 400 spectrometer using tetramethysilane as an internal standard in chloroform- $d\left(\mathrm{CDCl}_{3}\right)$ at room temperature (monomers) or $50^{\circ} \mathrm{C}$ (polymers).

Molecular weights $\left(M_{\mathrm{n}}\right)$ and molecular weight distributions $\left(M_{\mathrm{w}} / M_{\mathrm{n}}\right)$ were measured by means of gel permeation chromatography (GPC) on a Jasco-ChromNAV system equipped with a differential refractometer detector using tetrahydrofuran as eluent at a flow rate of $1.0 \mathrm{~mL} / \mathrm{min}$ at $40^{\circ} \mathrm{C}$, calibrated with poly(MMA) standards. The column used for the GPC analyses was a combination of Styragel HR4 (Waters; $300 \mathrm{~mm} \times$ $7.8 \mathrm{~mm}$ i.d., $5 \mu \mathrm{m}$ average particle size, exclusion molecular weight of $600 \mathrm{~K}$ for polystyrene) and Styragel HR2 (Waters; $300 \mathrm{~mm} \times 7.8 \mathrm{~mm}$ i.d., $5 \mu \mathrm{m}$ average particle size, exclusion molecular weight of $20 \mathrm{~K}$ for polystyrene), and poly(MMA) standards (Shodex M-75, $M_{\mathrm{n}}=200000, \quad M_{\mathrm{w}} / M_{\mathrm{n}}=1.05$, $M_{\mathrm{n}}=47300, M_{\mathrm{w}} / M_{\mathrm{n}}=1.02, M_{\mathrm{n}}=21700, M_{\mathrm{w}} / M_{\mathrm{n}}=1.02$, $\left.M_{\mathrm{n}}=5220, \quad M_{\mathrm{w}} / M_{\mathrm{n}}=1.06, \quad M_{\mathrm{n}}=2190, \quad M_{\mathrm{w}} / M_{\mathrm{n}}=1.08\right)$ and dibutyl sebacate $\left(M_{\mathrm{w}}=314.5\right)$ were used for the calibration.

Purification by preparative recycling GPC was performed on a JAI LC-918R equipped with a combination of columns of a JAIGEL-3H $(600 \mathrm{~mm} \times 20 \mathrm{~mm}$ i.d., exclusion molecular weight of $70 \mathrm{~K}$ for polystyrene) and a JAIGEL-2H $(600 \mathrm{~mm} \times 20 \mathrm{~mm}$ i.d., exclusion molecular weight of $20 \mathrm{~K}$ for polystyrene) using $\mathrm{CHCl}_{3}$ as eluent at a flow rate of $3.8 \mathrm{~mL} / \mathrm{min}$ at $25^{\circ} \mathrm{C}$. The sample solution $(3 \mathrm{~mL}$ containing $c a$. $0.3 \mathrm{~g}$ of the crude product) was injected and recycled before fractionation.

Elemental analyses were performed on a YANAKO MT-5 analyzer at Integrated Center for Science (INCS) in Ehime University.

\section{Preparation of $N$ - $n$-Hexyl Diazoacetamide 1 and $N$-Iso- propyl Diazoacetamide 3}

Caution: Although we have not experienced any explosions of diazocarbonyl compounds or their derivatives in our series of the studies, extra care should be taken for handling them because they could be potentially explosive.

Department of Material Science and Biotechnology, Graduate School of Science and Engineering, Venture Business Laboratory, Ehime University, 3 Bunkyo-cho, Matsuyama 790-8577, Japan

*To whom correspondence should be addressed (Tel/Fax: +81-89-927-8547, E-mail: ihara@eng.ehime-u.ac.jp). 
Diazoacetamide $\mathbf{1}$ and $\mathbf{3}$ were prepared following the procedure reported by Badet, B et al. ${ }^{7 \mathrm{a}}$ As an example, the procedure for $\mathbf{1}$ is described as follows. Under a nitrogen atmosphere, a THF $(30 \mathrm{~mL})$ solution of succinimidyl diazoacetate $(1.50 \mathrm{~g}, 8.20 \mathrm{mmol})$ was placed in a Schlenk tube. After $n$-hexylamine $(2.20 \mathrm{~mL}, 16.7 \mathrm{mmol})$ was added dropwise, the mixture was stirred at room temperature for $2 \mathrm{~h}$. After the volatiles were removed under reduced pressure, the product was purified by chromatography on silica gel with ethyl acetate as eluent to give $\mathbf{1}$ as a yellow solid $(1.23 \mathrm{~g}, 89.0 \%)$. The yield for 3 (a yellow solid) was also $89.0 \%$.

1: ${ }^{1} \mathrm{H}$ NMR $\left(400 \mathrm{MHz}, \mathrm{CDCl}_{3}\right) \delta 5.30(\mathrm{~s}, 1 \mathrm{H},-\mathrm{NH}-), 4.75$ (s, $1 \mathrm{H}, \mathrm{N}_{2} \mathrm{CH}-$ ), 3.27 (s, 2H, -NH-CH $2_{2}$ ), 1.50 (m, 2H, -NH$\left.\mathrm{CH}_{2} \mathrm{CH}_{2}-\right), 1.30$ (m, 6H, - $\left.\left(\mathrm{CH}_{2}\right)_{3}-\mathrm{CH}_{3}\right), 0.89$ (t, 3H, $\left.-\mathrm{CH}_{3}\right)$; ${ }^{13} \mathrm{C} \mathrm{NMR}\left(100 \mathrm{MHz}, \mathrm{CDCl}_{3}\right) \delta 165.9(\mathrm{C}=\mathrm{O}), 46.9\left(\mathrm{CN}_{2}\right), 40.1$ (-NH-CH $\left.2^{-}\right), 31.5$ (-NH-CH$\left.{ }_{2} \mathrm{CH}_{2}-\right), 29.9\left(-\mathrm{NH}-\mathrm{CH}_{2} \mathrm{CH}_{2} \mathrm{CH}_{2}-\right)$, $26.6\left(-\mathrm{CH}_{2} \mathrm{CH}_{2} \mathrm{CH}_{3}\right), 22.6\left(-\mathrm{CH}_{2} \mathrm{CH}_{3}\right), 14.0\left(-\mathrm{CH}_{3}\right)$. Anal. Calcd for $\mathrm{C}_{8} \mathrm{H}_{15} \mathrm{~N}_{3} \mathrm{O}$ : C, 56.78; H, 8.93; N, 24.83. Found: C, 56.59; H, 8.94; N, 24.29.

3: ${ }^{1} \mathrm{H}$ NMR (400 MHz, $\left.\mathrm{CDCl}_{3}\right) \delta 5.18(\mathrm{~s}, 1 \mathrm{H},-\mathrm{NH}-), 4.73$ (s, $\left.1 \mathrm{H}, \mathrm{N}_{2} \mathrm{CH}-\right), 4.09$ (s, 1H, -NH-CH( $\left.\left(\mathrm{CH}_{3}\right)_{2}\right), 1.16$ (d, $J=6.8$, $\left.6 \mathrm{H},-\mathrm{CH}\left(\mathrm{CH}_{3}\right)_{2}\right) ;{ }^{13} \mathrm{C} \mathrm{NMR}\left(100 \mathrm{MHz}, \mathrm{CDCl}_{3}\right) \delta 165.2(\mathrm{C}=\mathrm{O})$, $46.9\left(\mathrm{CN}_{2}\right), 41.9\left(-\mathrm{NH}-\mathrm{CH}\left(\mathrm{CH}_{3}\right)_{2}\right), 22.9\left(-\mathrm{CH}\left(\mathrm{CH}_{3}\right)_{2}\right)$. Anal. Calcd for $\mathrm{C}_{5} \mathrm{H}_{9} \mathrm{~N}_{3} \mathrm{O}$ : C, 47.23; H, 7.13; N, 33.05. Found: C, 47.31; H, 7.02; N, 32.32.

\section{Preparation of $N$-(4-n-Octyl)phenyl Diazoacetamide 2}

Diazoacetamide $\mathbf{2}$ was prepared following the reported procedure. ${ }^{7 \mathrm{~b}}$ Under a nitrogen atmosphere, a THF $(100 \mathrm{~mL})$ solution of glyoxylic acid tosylhydrazone $(6.00 \mathrm{~g}, 24.8 \mathrm{mmol})$ was placed in a round bottomed flask equipped with a dropping funnel and a three-way cock, and was cooled to $0{ }^{\circ} \mathrm{C}$. After 4- $n$ octylaniline $(5.2 \mathrm{~mL}, 23 \mathrm{mmol})$ was added, a THF $(30 \mathrm{~mL})$ solution of DCC $(5.20 \mathrm{~g}, 25.2 \mathrm{mmol})$ was added dropwise from the dropping funnel for $30 \mathrm{~min}$ at $0{ }^{\circ} \mathrm{C}$. The mixture was warmed to room temperature and stirred for $12 \mathrm{~h}$. After the precipitated urea was removed by filtration, the volatiles were removed under reduced pressure. The product was purified by chromatography on silica gel with an eluent (EtOAc: $\mathrm{CH}_{2} \mathrm{Cl}_{2}=1: 6$ ) to give $N$-4- $n$-octylphenylamide derivative of glyoxylic acid tosylhydrazone in a $49.0 \%$ yield. The product $(4.70 \mathrm{~g}, 11.0 \mathrm{mmol})$ was placed in a round bottomed flask and dissolved with $60 \mathrm{~mL}$ of $\mathrm{MeCN}$ under a nitrogen atmosphere. After $\mathrm{Et}_{3} \mathrm{~N}(3.1 \mathrm{~mL}, 22 \mathrm{mmol})$ was added, the mixture was stirred for $2 \mathrm{~h}$ at room temperature. After the precipitate was removed by filtration and the volatiles were removed under reduced pressure, the product was purified by chromatography on silica gel with an eluent (EtOAc:hexane $=1: 2)$ to give 2 as a yellow solid $(1.75 \mathrm{~g}, 58.0 \%)$.

${ }^{1} \mathrm{H}$ NMR (400 MHz, $\left.\left(\mathrm{CD}_{3}\right)_{2} \mathrm{SO}\right) \delta 9.63$ (s, 1H, -NH-), 7.44 (d, $J=7.6 \mathrm{~Hz}, 2 \mathrm{H}, \mathrm{Ar}-\mathrm{H}), 7.07$ (d, $J=8.4,2 \mathrm{H}, \mathrm{Ar}-\mathrm{H}), 5.47$ (s, 1H, $\left.\mathrm{N}_{2} \mathrm{CH}-\right), 3.37\left(\mathrm{~s}, 2 \mathrm{H},-\mathrm{C}_{6} \mathrm{H}_{4} \mathrm{CH}_{2}-\right), 1.52(\mathrm{~m}, 2 \mathrm{H}$, $\left.\left.-\mathrm{C}_{6} \mathrm{H}_{4} \mathrm{CH}_{2} \mathrm{CH}_{2}\right)^{-}\right), 1.25\left(\mathrm{~m}, 10 \mathrm{H},-\left(\mathrm{CH}_{2}\right)_{5}{ }^{-}\right), 0.85$ (t, $J=12.8$ $\left.\mathrm{Hz}, 3 \mathrm{H},-\mathrm{CH}_{3}\right) ;{ }^{13} \mathrm{C} \mathrm{NMR}\left(100 \mathrm{MHz},\left(\mathrm{CD}_{3}\right)_{2} \mathrm{SO}\right) \delta 163.3$ $(\mathrm{C}=\mathrm{O}), 137.3$ (Ar), 136.6 (Ar), 128.4 (Ar), 118.6 (Ar), $47.8\left(\mathrm{CN}_{2}\right), 34.6\left(-\mathrm{C}_{6} \mathrm{H}_{4} \mathrm{CH}_{2}-\right), 31.3\left(-\mathrm{C}_{6} \mathrm{H}_{4} \mathrm{CH}_{2} \mathrm{CH}_{2}-\right), 31.1$
$\left(-\mathrm{C}_{6} \mathrm{H}_{4} \mathrm{CH}_{2} \mathrm{CH}_{2} \mathrm{CH}_{2}-\right), 28.9\left(-\mathrm{C}_{6} \mathrm{H}_{4} \mathrm{CH}_{2} \mathrm{CH}_{2} \mathrm{CH}_{2} \mathrm{CH}_{2}-\right), 28.7$ $\left(-\mathrm{CH}_{2} \mathrm{CH}_{2} \mathrm{CH}_{2} \mathrm{CH}_{3}\right), 28.7\left(-\mathrm{CH}_{2} \mathrm{CH}_{2} \mathrm{CH}_{3}\right), 22.1\left(-\mathrm{CH}_{2} \mathrm{CH}_{3}\right)$, $13.9\left(-\mathrm{CH}_{3}\right)$. Anal. Calcd for $\mathrm{C}_{16} \mathrm{H}_{23} \mathrm{~N}_{3} \mathrm{O}: \mathrm{C}, 70.30 ; \mathrm{H}, 8.48 ; \mathrm{N}$, 15.37. Found: C, 70.22; H, 8.40; N, 15.28.

\section{Pd-mediated Polymerization of Diazoacetamides}

As a typical procedure for the polymerization of cyclic diazocarbonyl compounds, the procedure for run 3 in Table I is described as follows.

Under a nitrogen atmosphere, a suspension of $\mathrm{PdCl}_{2}$ $(\mathrm{MeCN})_{2}(6.0 \mathrm{mg}, 0.023 \mathrm{mmol})$ in toluene $(5 \mathrm{~mL})$ was placed in a Schlenk tube. After a toluene $(5 \mathrm{~mL})$ solution of a mixture of $1(0.196 \mathrm{~g}, 1.16 \mathrm{mmol})$ and $5(0.199 \mathrm{~g}, 1.16 \mathrm{mmol})$ was added to the suspension at room temperature, the resulting mixture was heated to $80^{\circ} \mathrm{C}$ and stirred for $14 \mathrm{~h}$ at the temperature. After the volatiles were removed under reduced pressure, $20 \mathrm{~mL}$ of $1 \mathrm{~N} \mathrm{HCl} / \mathrm{MeOH}, 20 \mathrm{~mL}$ of $1 \mathrm{~N} \mathrm{HCl}$ aqueous solution, and $30 \mathrm{~mL}$ of $\mathrm{CHCl}_{3}$ were added to the residue. After the organic layer was separated, the aqueous layer was extracted with $30 \mathrm{~mL}$ of $\mathrm{CHCl}_{3}$. The combined organic layer was washed with $50 \mathrm{~mL}$ of $1 \mathrm{~N} \mathrm{HCl}$ aqueous solution and $50 \mathrm{~mL}$ of $\mathrm{H}_{2} \mathrm{O}$, dried over $\mathrm{Na}_{2} \mathrm{SO}_{4}$, filtered, and concentrated under reduced pressure to afford a crude product. Purification with preparative recycling GPC gave the copolymer $(100 \mathrm{mg}$, $32.0 \%$ ) as a dark brown solid.

Other polymerizations in Table I were carried out in similar procedures.

Poly1': ${ }^{1} \mathrm{H}$ NMR $\left(400 \mathrm{MHz}, \mathrm{CDCl}_{3}\right) \delta$ 2.8-3.6 (-NH-CH $\left.2^{-}\right)$, 1.4-2.0 (-NH-CH$\left.{ }_{2} \mathrm{CH}_{2}-\right), 1.1-1.4\left(-\left[\mathrm{CH}_{2}\right]_{3}-\right), 0.8-1.0\left(\mathrm{CH}_{3}\right)$. Poly2': ${ }^{1} \mathrm{H}$ NMR $\left(400 \mathrm{MHz}, \mathrm{CDCl}_{3}\right) \delta$ 6.7-7.8 $\left(-\mathrm{C}_{6} \mathrm{H}_{4}-\right), 2.3-$ 2.7 (-Ar- $\left.\mathrm{CH}_{2}-\right), 1.5-1.8\left(-\mathrm{Ar}^{-} \mathrm{CH}_{2} \mathrm{CH}_{2}-\right), 1.1-1.5\left(-\left[\mathrm{CH}_{2}\right]_{5}-\right)$, 0.8-1.0 $\left(-\mathrm{CH}_{3}\right)$. Poly $\left(\mathbf{1}^{\prime}-\right.$ ran $\left.-\mathbf{5}^{\prime}\right):{ }^{1} \mathrm{H}$ NMR $\left(400 \mathrm{MHz}, \mathrm{CDCl}_{3}\right)$ $\delta$ 6.0-8.0 $\left(\mathrm{C}_{6} \mathrm{H}_{5}-\mathrm{CH}=\mathrm{CH}-\right), 4.0-5.7$ (main chain $\mathrm{CH}$ ), 2.7-3.6 (-NH-CH $\left.2^{-}\right), 1.0-2.0\left(-\left[\mathrm{CH}_{2}\right]_{4}-\right), 0.6-1.0\left(-\mathrm{CH}_{3}\right)$. Poly $\left(\mathbf{2}^{\prime}\right.$-ran$\left.\mathbf{5}^{\prime}\right):{ }^{1} \mathrm{H} \mathrm{NMR}\left(400 \mathrm{MHz}, \mathrm{CDCl}_{3}\right) \delta 6.0-7.8\left(\mathrm{C}_{6} \mathrm{H}_{5}-\mathrm{CH}=\mathrm{CH}-\right)$, 3.2-5.5 (main chain $\mathrm{CH}), 2.2-2.8\left(-\mathrm{Ar}-\mathrm{CH}_{2}-\right)$, 1.4-1.9 (-Ar$\left.\mathrm{CH}_{2} \mathrm{CH}_{2}-\right), 1.0-1.4\left(-\left[\mathrm{CH}_{2}\right]_{5}-\right), 0.7-1.0\left(-\mathrm{CH}_{3}\right)$. Poly $\left(\mathbf{3}^{\prime}-\right.$ ran $\left._{-} \mathbf{5}^{\prime}\right)$ : ${ }^{1} \mathrm{H}$ NMR $\left(400 \mathrm{MHz}, \mathrm{CDCl}_{3}\right) \delta$ 6.1-7.9 $\left(\mathrm{C}_{6} \mathrm{H}_{5}-\mathrm{CH}=\mathrm{CH}-\right), 4.4-$ 5.7 (main chain $\mathrm{CH}), \quad 3.8-4.4 \quad\left(-\mathrm{CH}\left[\mathrm{CH}_{3}\right]_{2}\right), \quad 0.3-2.0$ $\left(-\mathrm{CH}\left[\mathrm{CH}_{3}\right]_{2}\right)$. Poly $\left(4^{\prime}-\right.$ ran $\left.^{-5}\right)$ : ${ }^{1} \mathrm{H} \mathrm{NMR}\left(400 \mathrm{MHz}, \mathrm{CDCl}_{3}\right) \delta$ 6.0-8.0 $\left(\mathrm{C}_{6} \mathrm{H}_{5}-\mathrm{CH}=\mathrm{CH}-\right.$ ), 4.3-5.7 (main chain $\mathrm{CH}$ ), 2.4-4.0 (- $\left.\mathrm{CH}_{2}-\left[\mathrm{CH}_{2}\right]_{3}-\mathrm{CH}_{2}-\right), 0.6-2.4\left(-\mathrm{CH}_{2}-\left[\mathrm{CH}_{2}\right]_{3}-\mathrm{CH}_{2}-\right)$. Signals for $\mathrm{NH}$ for all the polymers and main chain $\mathrm{CH}$ signals for poly $\mathbf{1}^{\prime}$ and poly $2^{\prime}$ could not be identified.

\section{RESULTS AND DISCUSSION}

\section{Hompolymerization of Diazoacetamides 1-4}

According to the procedures reported in the literatures, ${ }^{7}$ we prepared four diazoacetamides 1-4, three (1-3) of which are new compounds. Among the four diazo compounds, 1 and $\mathbf{2}$ could be transformed into homopolymers by the reaction with $\mathrm{PdCl}_{2}(\mathrm{MeCN})_{2}$, whereas $\mathbf{3}$ and $\mathbf{4}$ with relatively bulky substituents at the amide- $N$ did not give polymeric products under the same condition, probably because steric congestion around Pd-center during propagation ${ }^{4 a, b}$ is too severe for $\mathbf{3}$ and 
Table I. Polymerization of Diazoacetamides 1,2 and Copolymerization of Diazoacetamides 1-4 with (E)-1-Diazo-4-phenyl-3-buten-2-one 5a

\begin{tabular}{|c|c|c|c|c|c|c|c|c|}
\hline run & $\begin{array}{l}\text { monomer } 1 \text {, } \\
\qquad \begin{array}{l}\text { (M1) } \\
\text { mmol }\end{array}\end{array}$ & $\begin{array}{l}\text { monomer } 2 \text {, } \\
\text { (M2) } \\
\text { mmol }\end{array}$ & $\begin{array}{l}\text { feed ratio } \\
{[\mathrm{M} 1]:[\mathrm{M} 2]}\end{array}$ & $\begin{array}{l}\text { yield }^{b} \\
(\%)\end{array}$ & $M_{\mathrm{n}}{ }^{\mathrm{c}}$ & $M_{\mathrm{w}} / M_{\mathrm{n}}{ }^{\mathrm{c}}$ & $\begin{array}{l}\text { composition in } \\
\text { copolymer } \\
\mathrm{M} 1^{\prime}: \mathrm{M}^{\prime} \mathrm{d} \\
\left({ }^{1} \mathrm{H} \text { NMR }\right)\end{array}$ & $\begin{array}{c}\text { elemental analysis } \\
\text { found calcd for } \\
\mathrm{Cl}\left(\mathrm{M} 1^{\prime}\right)_{\mathrm{m}}\left(\mathrm{M} 2^{\prime}\right)_{\mathrm{n}}(-\mathrm{N}=\mathrm{N}-)_{\mathrm{p}} \mathrm{Cl}, \mathrm{M}_{\mathrm{n}}\end{array}$ \\
\hline 1 & $1,2.31$ & - & - & 10.7 & 990 & 1.12 & - & $\begin{array}{l}\mathrm{C}, 62.94 ; \mathrm{H}, 9.61 ; \mathrm{N}, 12.13 \\
\mathrm{C}, 61.54 ; \mathrm{H}, 9.68 ; \mathrm{N}, 12.05\left(\mathrm{~m} / \mathrm{p}=7.0: 1.2, M_{\mathrm{n}}=1090\right)\end{array}$ \\
\hline 2 & $\mathbf{1}, 1.54$ & $5,0.77$ & $2: 1$ & 28.7 & 1050 & 1.20 & $2.5: 1$ & \\
\hline 3 & $1,1.16$ & $5,1.16$ & $1: 1$ & 31.5 & 1260 & 1.31 & 1.3:1 & $\begin{array}{l}\mathrm{C}, 67.76 ; \mathrm{H}, 7.34 ; \mathrm{N}, 11.15 \\
\mathrm{C}, 66.51 ; \mathrm{H}, 7.47 ; \mathrm{N}, 11.15\left(\mathrm{~m} / \mathrm{n} / \mathrm{p}=5.0: 4.0: 3.3, M_{\mathrm{n}}=1440\right)\end{array}$ \\
\hline 4 & $1,0.77$ & $5,1.54$ & $1: 2$ & 39.2 & 1270 & 1.29 & $1: 1.8$ & \\
\hline 5 & $2,2.31$ & - & - & 9.1 & 1890 & 1.10 & - & $\begin{array}{l}\text { C, 75.77; H, 9.18; N, } 7.70 \\
\text { C, 73.62; H, 8.88; N, } 7.60\left(m / p=7.2: 1.5, M_{n}=1880\right)\end{array}$ \\
\hline 6 & $2,1.54$ & $5,0.77$ & $2: 1$ & 43.7 & 1420 & 1.23 & 4.3:1 & \\
\hline 7 & $2,1.16$ & $5,1.16$ & $1: 1$ & 35.1 & 1440 & 1.25 & $2.6: 1$ & \\
\hline 8 & $2,0.77$ & $5,1.54$ & $1: 2$ & 31.3 & 1520 & 1.32 & $1: 0.8$ & $\begin{array}{l}\text { C, 74.19; H, 7.41; N, } 7.45 \\
\text { C, 73.04; H, 7.41; N, } 7.48\left(m / n / p=3.7: 3.3: 2.2, M_{n}=1520\right)\end{array}$ \\
\hline 9 & 3, 1.54 & $5,0.77$ & $2: 1$ & 25.7 & 650 & 1.48 & $2.6: 1$ & \\
\hline 10 & $3,1.16$ & $5,1.16$ & $1: 1$ & 26.6 & 750 & 1.51 & $1.6: 1$ & \\
\hline 11 & $3,0.77$ & $5,1.54$ & $1: 2$ & 34.7 & 1020 & 1.43 & $1: 1.4$ & $\begin{array}{l}\mathrm{C}, 69.01 ; \mathrm{H}, 5.88 ; \mathrm{N}, 9.19 \\
\mathrm{C}, 66.65 ; \mathrm{H}, 6.12 ; \mathrm{N}, 8.73\left(\mathrm{~m} / \mathrm{n} / \mathrm{p}=3.3: 4.0: 1.5, M_{\mathrm{n}}=1010\right)\end{array}$ \\
\hline 12 & $4,1.54$ & $5,0.77$ & $2: 1$ & 52.5 & 450 & 1.61 & $2.0: 1$ & \\
\hline 13 & $4,1.16$ & $5,1.16$ & $1: 1$ & 41.3 & 720 & 1.44 & $1.1: 1$ & $\begin{array}{l}\text { C, 69.50; H, 6.34; N, } 8.05 \\
\text { C, 66.58; H, 6.48; N, } 7.85\left(m / n / p=3.1: 2.5: 0.8, M_{n}=840\right)\end{array}$ \\
\hline 14 & $4,0.77$ & $5,1.54$ & $1: 2$ & 49.0 & 840 & 1.44 & $1: 1.8$ & \\
\hline
\end{tabular}

$\left.{ }^{\mathrm{a}}([\mathrm{M} 1]+[\mathrm{M} 2]) /\left[\mathrm{PdCl}_{2}(\mathrm{MeCN})_{2}\right]\right)=100$, toluene $=10 \mathrm{~mL}$; polymerization period $=14 \mathrm{~h}$; polymerization temperature $=80^{\circ} \mathrm{C}$.

${ }^{b}$ Yield $(\%)=100 \times$ (the weight of the product after purification with the recycling GPC - the weight of $\mathrm{N}$ contained in the product calculated from the result of elemental analysis)/(total amount monomers - the weight of $\mathrm{N}$ contained in the monomers). For the copolymer samples without elemental analysis data, the yield was calculated on the assumption that $\left[\mathrm{M}^{\prime}{ }^{\prime}\right]:[-\mathrm{N}=\mathrm{N}-]$ is the same as that obtained by elemental analysis for other sample with the same comonomer combination but a different feed ratio.

${ }^{c} M_{\mathrm{n}}$ and $M_{\mathrm{w}} / M_{\mathrm{n}}$ were obtained by GPC calibration using standard PMMAs in THF solution.

${ }^{\mathrm{d}} \mathrm{M} 1^{\prime}=$ repeating unit derived from $\mathrm{M} 1$.

$$
\text { 2; } \mathrm{R}=-n-\mathrm{C}_{6}
$$

Scheme 1. Pd-mediated Polymerization of Diazoacetamides 1,2.

4 (Scheme 1). For example, when the reaction of 2 with $1 \mathrm{~mol} \%$ of $\mathrm{PdCl}_{2}(\mathrm{MeCN})_{2}$ was conducted in toluene at $80^{\circ} \mathrm{C}$ for $14 \mathrm{~h}$, a polymeric product was obtained, whose GPCestimated $M_{\mathrm{n}}$ (based on PMMA standards) was 1890 (run 5 in Table I). ${ }^{1} \mathrm{H}$ NMR spectrum for the product shown in Figure 1(b) exhibits broad signals assignable to each $\mathrm{H}$ in the amide-substituent $\left(-\mathrm{C}_{6} \mathrm{H}_{4}-n-\mathrm{C}_{8} \mathrm{H}_{17}\right)$ of 2 , which apparently suggests the progress of the Pd-mediated polymerization of $\mathbf{2}$ in the similar manner as diazoacetates and diazoketones, ${ }^{4}$ although the main chain $\mathrm{CH}$ and $\mathrm{NH}$ peaks cannot be identified in the spectrum probably due to broadening of the signals. The result of the elemental analysis for the sample indicates that its $\mathrm{N}$ content $(7.70 \%)$ is significantly higher than that expected for (a)

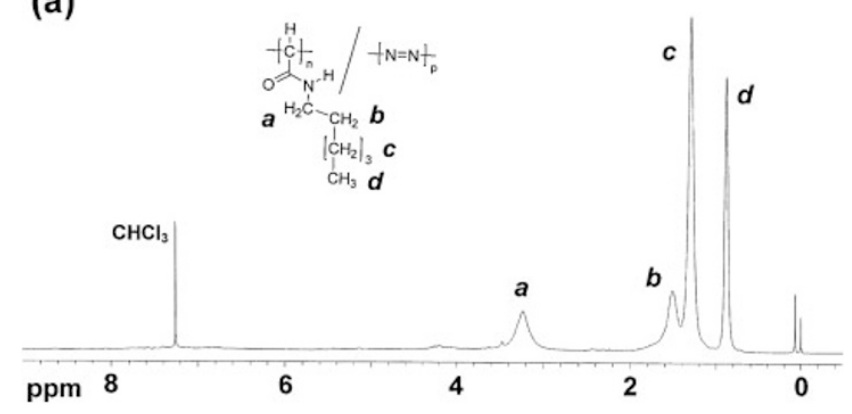

(b)

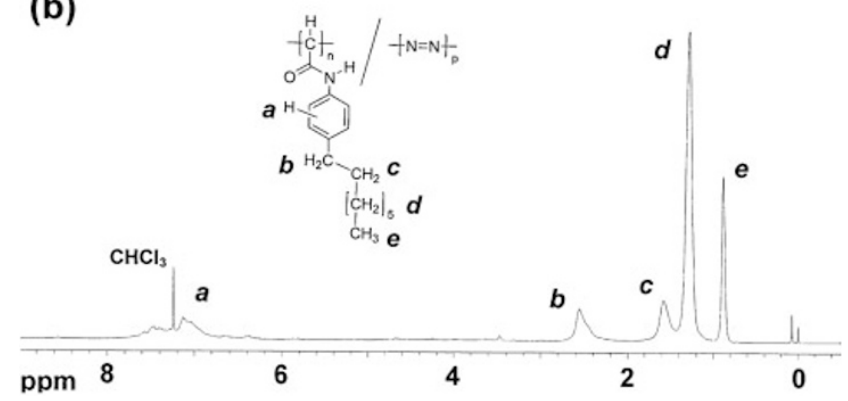

Figure 1. ${ }^{1} \mathrm{H}$ NMR spectra of polymers from 1 (a) and 2 (b) (runs 1 and 5, respectively, Table I). 
the polymer obtained via complete removal of $\mathrm{N}_{2}$ from the monomer $(\mathrm{N}=5.71 \%)$. Accordingly, the partial incorporation of azo group should occur during the polymerization as proposed in the Pd-mediated polymerization of diazoketones. ${ }^{4 \mathrm{~b}}$ On the assumption that $\mathrm{Cl}$ derived from the initiator attached to both chain ends, ${ }^{4 b}$ the calculated values based on the composition with $17.2 \mathrm{~mol} \%$ of the azo group agree with the observed values as listed in Table I. The degree of the azoincorporation is much higher than that observed for the Pdmediated polymerization of diazoketones $(<5 \mathrm{~mol} \%){ }^{4 \mathrm{~b}} \mathrm{Sim}-$ ilarly, homopolymerization of $\mathbf{1}$ proceeded to give a polymer, whose GPC-estimated $M_{\mathrm{n}}$ was 990 and azo content in the main chain determined from elemental analysis was $14.6 \mathrm{~mol} \%$ (run 1). Figure 1(a) shows the ${ }^{1} \mathrm{H}$ NMR spectrum for the product, which exhibits broad signals derived from the $N$-hexyl side chain. The much lower $M_{\mathrm{n}}$ of poly $\mathbf{1}^{\prime}\left(\mathbf{1}^{\prime}=\right.$ repeating unit derived from 1) compared to poly $2^{\prime}$ may indicate that the presence of $\pi$-electrons in the vicinity of diazocarbonyl moiety plays an important role for the polymerization to proceed, as demonstrated in the Pd-mediated polymerization of various diazoketones. ${ }^{4 \mathrm{~b}}$ Although the yields for the homopolymerizations were rather low ( $\mathrm{ca}$. 10\%), these results demonstrate that polymers whose all the main chain carbons bear $N$-substituted carbamoyl group can be obtained by the Pd-mediated polymerization of some diazoacetamides.

\section{Copolymerization of Diazoacetamides (1-4) with $(E)-1$ - Diazo-4-phenyl-3-buten-2-one (5)}

Next, we examined copolymerization of diazoacetamides 14 with (E)-1-diazo-4-phenyl-3-buten-2-one 5, whose homopolymerization mediated by $\mathrm{PdCl}_{2}(\mathrm{MeCN})_{2}$ in toluene at $80^{\circ} \mathrm{C}$ has been demonstrated to afford polymers with $M_{\mathrm{n}}=1740$ in a $63.3 \%$ yield. $^{4 \mathrm{~b}}$ As summarized in Table I, all the four diazo compounds 1-4 can be copolymerized including 3 and $\mathbf{4}$, which did not afford polymers for their homopolymerization as described above (Scheme 2). For example, a mixture of $\mathbf{1}$ and $\mathbf{5}$ in a 1:1 molar ratio was reacted with $\mathrm{PdCl}_{2}(\mathrm{MeCN})_{2}([\mathrm{Pd}] \times$ $100=[\mathbf{1}]+[\mathbf{5}])$ in toluene at $80^{\circ} \mathrm{C}$ for $14 \mathrm{~h}$, giving a polymeric product whose GPC-estimated $M_{\mathrm{n}}$ calibrated with PMMA standards was 1260 (run 3). As shown in Figure 2, the ${ }^{1} \mathrm{H}$ NMR spectrum for the product exhibits broad signals assignable to each $\mathrm{H}$ in the repeating units of $\mathbf{1}$ and $\mathbf{5}$. In this case, broad signals that should be ascribed to main chain $\mathrm{C}-\mathrm{Hs}$ for $\mathbf{1}^{\prime}$ and/or $\mathbf{5}^{\prime}$ are observed at 4.0-5.7 ppm. The composition of the two repeating units can be calculated from the integral ratio between the broad signals for $\mathrm{CH}_{3}$ at $0.6-1.0 \mathrm{ppm}\left(\mathbf{1}^{\prime}\right)$ and $\mathrm{C}_{6} H_{5} \mathrm{CH}=\mathrm{CH}$ at $6.0-8.0 \mathrm{ppm}\left(\mathbf{5}^{\prime}\right)$, to be $\left[\mathbf{1}^{\prime}\right]:\left[\mathbf{5}^{\prime}\right]=1.3: 1 .{ }^{8}$

As listed in Table I, the observed values for the elemental analysis of the product agree with the calculated values for the structure with the composition of $\left[\mathbf{1}^{\prime}\right]:\left[\mathbf{5}^{\prime}\right]=1.3: 1$ and $M_{\mathrm{n}}=$ 1440. The calculation was also based on the assumption that the polymer has $\mathrm{Cl}$ at both chain ends and the azo content in the main chain is $26.8 \mathrm{~mol} \%$. On the basis of the composition, the yield of the polymer is $31.5 \%$. In a similar manner, copolymerization with feed ratios of $[\mathbf{1}]:[\mathbf{5}]=2: 1$ and $1: 2$ proceeded to give copolymers with compositions corresponding to the
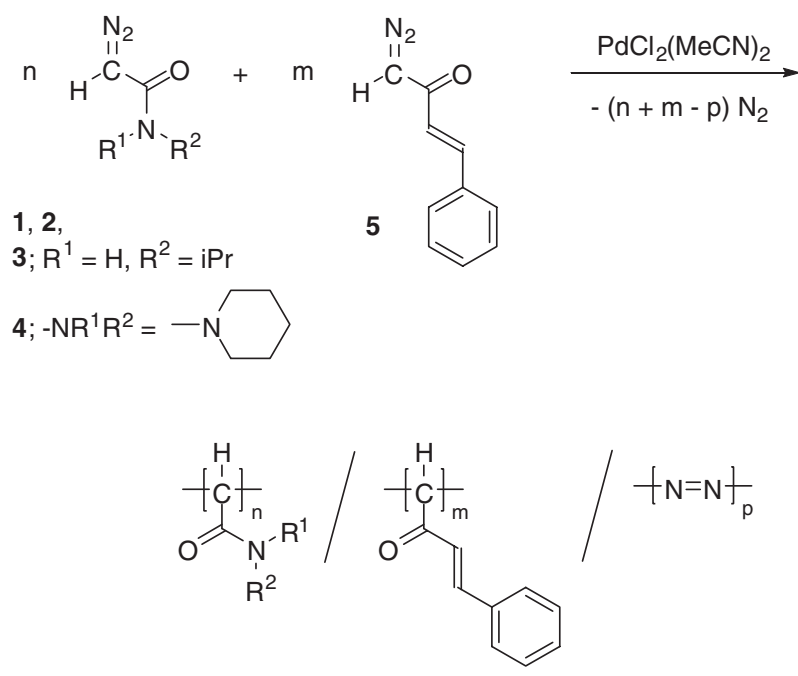

Scheme 2.

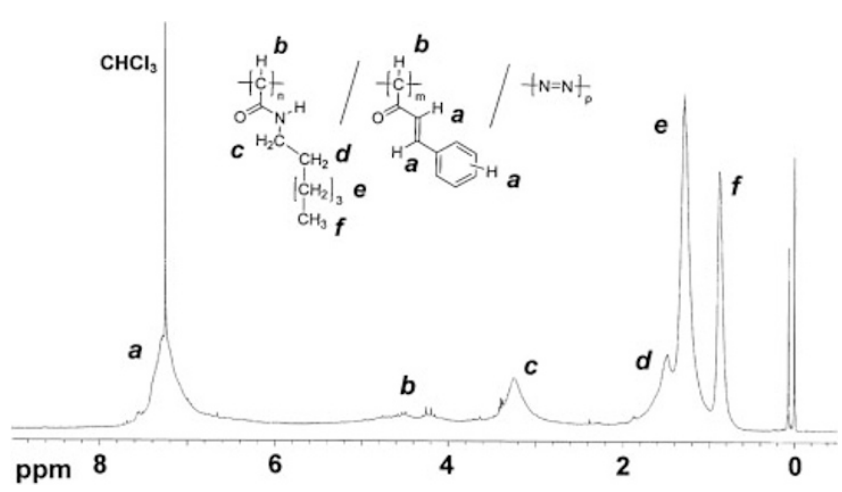

Figure 2. ${ }^{1} \mathrm{H}$ NMR spectrum of a copolymer from $\mathbf{1}$ and $\mathbf{5}$ (run 3, Table I).

feed ratios (runs 2 and 4). Reflecting the low reactivity of $\mathbf{1}$ compared to $\mathbf{5}$ toward homopolymerization, the $M_{\mathrm{n}} \mathrm{s}$ and yields of the resulting poly $\left(\mathbf{1}^{\prime}-\right.$ ran $\left.-\mathbf{5}^{\prime}\right)$ were lower than those of the poly $\mathbf{5}^{\prime}$ obtained under the same condition.

When 2 was used as a diazoacetamide for the copolymerization with $\mathbf{5}$, the composition of $\mathbf{2}$ in the resulting copolymer is much higher than that expected from the feed ratio, which clearly indicates the higher relative reactivity of $\mathbf{2}$ than $\mathbf{5}$ in the copolymerization, whereas the composition of the copolymers changed corresponding to the feed ratio (runs 6-8). In addition, $M_{\mathrm{n}} \mathrm{s}$ of poly $\left(\mathbf{2}^{\prime}-\operatorname{ran}^{-5^{\prime}}\right) \mathrm{s}$ are much higher than those of poly $\left(\mathbf{1}^{\prime}-\right.$ ran-5's in runs $2-4$. The high reactivity of $\mathbf{2}$ could again be ascribed to the presence of the aromatic ring in the monomer structure. The copolymerization with [2]:[5] = 1:2 gave a copolymer, whose observed elemental analysis values agreed with the calculated values for the structure with a NMRdetermined composition and GPC-estimated $M_{\mathrm{n}}$ (run 8).

The non-homopolymerizable diazoacetamides $\mathbf{3}$ and $\mathbf{4}$ could be used for the copolymerization with 5 (runs 9-14). The progress of the copolymerization of $\mathbf{3}$ and $\mathbf{4}$ with $\mathbf{5}$ supports our assumption mentioned above that the monomers cannot be homopolymerized because of the steric reason derived from 
their substituents although the diazocarbonyl groups have potential to be polymerized. However, probably because the monomer structures of $\mathbf{3}$ and $\mathbf{4}$ with bulky substituents may be sterically unfavorable for the Pd-centered propagating center even in the copolymerization, the $M_{\mathrm{n}} \mathrm{s}$ of the copolymers are relatively low, and they become lower with the increase of the feed ratio of $\mathbf{3}$ and $\mathbf{4}$. On the other hand, the composition of the copolymers corresponds to the monomer feed ratio, indicating that the relative reactivity of $\mathbf{3}$ and $\mathbf{4}$ is close to that of diazoketone 5. The repeating unit structure derived from $\mathbf{3}$ is of interest because it could be regarded as poly(substituted methylene) analogue of poly( $N$-isopropylacrylamide), whose unique thermo-responsive property has been well known. ${ }^{9}$ The compositions for those copolymers obtained from $\mathbf{3}$ and $\mathbf{4}$ were also determined from ${ }^{1} \mathrm{H}$ NMR and elemental analyses.

\section{CONCLUSIONS}

We have demonstrated that diazoacetamides can be polymerized to give polymers having $N$-substituted carbamolymethylene as a repeating unit. Although the $M_{\mathrm{n}} \mathrm{s}$ of the resulting polymers are rather low, the polymer structures with $\mathrm{N}$-substituted carbamolymethylene repeating units obtained here are unprecedented and would be expected to have unique properties.

Acknowledgment. This research was supported by the Grants-in-Aid for Scientific Research (B) (No. 18350066) from Japan Society for the Promotion of Science (JSPS).

Received: June 30, 2008

Accepted: August 6, 2008

Published: September 18, 2008

\section{REFERENCES}

1. J. Bai, L. D. Burke, and K. D. Shea, J. Am. Chem. Soc., 129, 4981 (2007).
2. E. Ihara, M. Kida, T. Itoh, and K. Inoue, J. Polym. Sci., Part A: Polym. Chem., 45, 5209 (2007).

3. L. Liu, Y. Song, and H. Li, Polym. Int., 51, 1047 (2002).

4. (a) E. Ihara, N. Haida, M. Iio, and K. Inoue, Macromolecules, 36, 36 (2003).

(b) E. Ihara, M. Fujioka, N. Haida, T. Itoh, and K. Inoue, Macromolecules, 38, 2101 (2005).

(c) E. Ihara, A. Nakada, T. Itoh, and K. Inoue, Macromolecules, 39, 6440 (2006).

(d) E. Ihara, M. Kida, M. Fujioka, N. Haida, T. Itoh, and K. Inoue, J. Polym. Sci., Part A: Polym. Chem., 45, 1536 (2007).

(e) E. Ihara, T. Hiraren, T. Itoh, and K. Inoue, J. Polym. Sci., Part A: Polym. Chem., 46, 1638 (2008).

5. (a) D. G. H. Hetterscheid, C. Hendriksen, W. I. Dzik, J. M. M. Smits, E. R. H. van Eck, A. E. Rowan, V. Busico, M. Vacatello, V. V. A. Castelli, A. Segre, E. Jellema, T. G. Bloemberg, and B. de Bruin, J. Am. Chem. Soc., 128, 9746 (2006).

(b) E. Jellema, P. H. M. Budzelaar, J. N. H. Reek, and B. de Bruin, J. Am. Chem. Soc., 129, 11631 (2007).

6. T. Oyama, T. Fukui, K. Naka, and Y. Chujo, Polym. Bull., 43, 183 (1999).

7. (a) A. Ouihia, L. Rene, J. Guilhem, C. Pascard, and B. Badet, J. Org. Chem., 58, 1641 (1993).

(b) A. Ouihia, L. Rene, and B. Badet, Tetrahedron Lett., 33, 5509 (1992).

8. Although the signal in the aromatic region derived from $\mathbf{5}^{\prime}$ apparently overlaps with the residual $\mathrm{CHCl}_{3}$ signal, the integral ratio for the latter was excluded for the calculation of the composition by using the paper weight of the peak areas throughout this study.

9. (a) T. Maeda, K. Yamamoto, and T. Aoyagi, J. Colloid Interface Sci., 302, 467 (2006).

(b) H. Wakamatsu, K. Yamamoto, A. Nakao, and T. Aoyagi, J. Magn. Magn. Mater., 302, 327 (2006).

(c) T. Maeda, M. Takenouchi, K. Yamamoto, and T. Aoyagi, Biomacromolecules, 7, 2230 (2006).

(d) D. Matsukuma, K. Yamamoto, and T. Aoyagi, Langmuir, 22, 5911 (2006).

(e) T. Maeda, T. Kanda, Y. Yonekura, K. Yamamoto, and T. Aoyagi, Biomacromolecules, 7, 545 (2006).

10. R. L. Danheiser, R. F. Miller, R. G. Brisbois, and S. Z. Park, J. Org. Chem., 55, 1959 (1990).

11. C. J. Blankley, F. J. Sauter, and H. O. House, "Organic Synthesis," Wiley, New York, 1973, Collect. Vol. V, p 258.

12. L. S. Hegedus, "Organometallics in Synthesis. A Manual," M Schlosser, Ed., John Wiley and Sons, West Sussex, 2002, p 1126. 